\section{Gibberellic Acid Sensitivity among Common Bean Cultivars (Phaseolus vulgaris L.)}

\author{
Alexander D. Pavlista ${ }^{1,5}$, Dipak K. Santra ${ }^{2}$, James A. Schild ${ }^{3}$, \\ and Gary W. Hergert ${ }^{4}$ \\ Department of Agronomy and Horticulture, University of Nebraska, Panhandle \\ Research and Extension Center, 4502 Avenue I, Scottsbluff, NE 69361
}

Additional index words. dry edible bean, plant growth stimulant, gibberellin, $\mathrm{GA}_{3}$

\begin{abstract}
To lower seed yield loss from directly harvested common bean or dry bean, height of the lower pod-bearing nodes needs to be raised. The objective of this greenhouse study was to stimulate lower stem elongation by gibberellic acid $\left(\mathrm{GA}_{3}\right)$ of dry bean cultivars. Seeds of cv. Matterhorn, erect indeterminate Type II, and cv. Poncho, prostate indeterminate Type III, were dipped in $\mathrm{GA}_{3}$ at 62.5 to $16,000 \mathrm{ppm}$ and planted. After $14 \mathrm{~d}$, the height of the unifoliate and first trifoliate nodes showed maximum stimulation of stem elongation by $1000 \mathrm{ppm} \mathrm{GA}_{3}$ for 'Poncho' and by $2000 \mathrm{ppm}$ for 'Matterhorn'. Application of $1 \mathrm{~mL}$ of $\mathrm{GA}_{3}$ at 0.031 to $2048 \mathrm{ppm}$ to newly expanded unifoliate leaves showed cultivar differences. Whereas 'Matterhorn' was promoted at $64 \mathrm{ppm}$ and reached a maximum height by $512 \mathrm{ppm} \mathrm{GA}_{3}$, 'Poncho' was promoted at $0.25 \mathrm{ppm}$ and reached a maximum height by 8 ppm $\mathrm{GA}_{3}$. Flowering of 'Matterhorn' was unaffected by $\mathbf{G A}_{3}$; flowering of 'Poncho' was completely inhibited by $128 \mathrm{ppm}$. The sensitivity difference of cultivars was verified with other cultivars. Type I cultivars, which are all determinate, showed a full range of $\mathrm{GA}_{3}$ sensitivity. Dry bean cultivars may be regrouped based on the $\mathrm{GA}_{3}$ dose to which they respond. Individual response to $\mathrm{GA}_{3}$ rates of dry bean cultivars needs to be predetermined using a short-term, 2-3 weeks, greenhouse bioassay before field use of $\mathrm{GA}_{3}$.
\end{abstract}

In dry bean (Phaseolus vulgaris L.), growth form, i.e., determinate vs. indeterminate, and growth habit, i.e., upright/erect/bushy vs. viny/ prostate, are among the most important characteristics for classifying cultivars from an agronomic viewpoint (Kelly, 2001; Laing et al., 1984; Singh, 1982). Dry bean is morphologically classified as determinate or indeterminate growth forms depending on whether the terminal meristem is reproductive (determinate) or vegetative (indeterminate) (Miklas and Singh, 2007). This characteristic is genetically controlled by the gene Finfin and unaffected by the environment (Koinange et al., 1996). Having a determinate terminal meristem was the result of FinFin or Finfin that is dominant over an indeterminate type (finfin) and this probably evolved through natural mutation of the wild-type Fin gene (Gepts, 1998). Indeterminate agronomic cultivars were classified into Type II and Type III based on vine growth extension and climbing ability. Determinate cultivars were classified as Type I and subdivided by their climbing ability. North

Received for publication 5 Dec. 2011. Accepted for publication 4 Apr. 2012.

We thank Bob Hawley and Les Kampbell for their technical assistance and the financial support by the Nebraska Dry Bean Commission.

${ }^{1}$ Crop Physiologist.

${ }^{2}$ Alternate Crop Breeder.

${ }^{3}$ Extension Educator.

${ }^{4}$ Soil Scientist.

${ }^{5}$ To whom reprint requests should be addressed; e-mailapavlista@unl.edu.
American-grown commercial dry bean cultivars are described by Singh (1982) as:

Type $\mathrm{I}=$ determinate, erect (bushy). Further classified into Ia (no climbing ability) and $\mathrm{Ib}$ (some climbing ability);

Type II = indeterminate, erect (bushy). Further classified into IIa (no climbing ability) and IIb (some climbing ability = semiclimbing); and

Type III = indeterminate, prostrate (viny). Further classified into IIIa (some climbing ability = semiclimbing) and IIIb (strong climbing ability = climbing).

Vine length is highly affected by environment conditions, especially light (Kelly, 2001; Singh, 2001). The climbing phenotype of dry bean may be the result of a dominant gene, $C 1$, whereas the nonclimbing types may be the result of a recessive gene, $c l$, that has evolved through natural mutation of $C 1$ (Gepts, 1998; Kretchmer and Wallace, 1978).

Type II and III dry bean cultivars are the most common ones grown in the U.S. High Plains. The lower pods of common dry bean grown in the field are very close to the ground. Because of this, the conventional practice in dry bean production in the U.S. High Plains is to harvest by first undercutting plants, conventional harvest, to minimize yield loss (Smith, 2004). The alternate method of harvest is direct harvesting but the yield loss in the Nebraska Panhandle may be greater than $10 \%$ even with the addition of lifters (Smith, 2004). In the Red River Valley, the mean of nine cultivars grown in four North Dakota locations over 2 years, seed yield was reduced from 2240 for conventional harvest to $1410 \mathrm{~kg} \cdot \mathrm{ha}^{-1}$ for direct harvest or $27 \%$ (Eckert et al., 2011). Most of the yield reduction was the result of seed loss during harvest, $4.5 \%$ by conventional harvest vs. $23.2 \%$ by direct harvest (Eckert et al., 2011).

One possible method of reducing yield loss is to stimulate growth of lower internodes, those below the node with the first flower and pod, to raise lower pods higher off the ground and allow the cutting blades on a direct harvester to cut the stem below those pods. This may be accomplished by application of a growth-stimulating compound such as $\mathrm{GA}_{3}$.

The ability of gibberellins to promote stem growth was known since the 1930s when a rice disease was identified to be the result of a pathogenic fungus Gibberella fujikuroi (Takahashi et al., 1991). Since then, there have been more than 130 gibberellins identified. Gibberellic acid, a key gibberellin, is highly active and well known to stimulate stem elongation (Davies, 2010; Marth et al., 1956). A greenhouse bioassay for $\mathrm{GA}_{3}$ applied to fully opened unifoliate leaves of snap bean cultivars ( $P$. vulgaris) was developed showing a dose-response for stimulating stem elongation and exposure between 2 and $10 \mu \mathrm{g}$ $\mathrm{GA}_{3} /$ plant for maximum effect (Knoche et al., 1998, 2000).

The objective of this study was to compare the $\mathrm{GA}_{3}$ dose-response of indeterminate dry bean cultivars with an erect, upright (Type II) growth or a prostate (Type III) growth habit and determinate cultivars (Type I).

\section{Materials and Methods}

Greenhouse conditions. Experiments were conducted in March and April of 2005, 2006, and 2007 in a greenhouse at the Panhandle Research \& Extension Center of the University of Nebraska in Scottsbluff (lat. $41.9^{\circ} \mathrm{N}$, long. $103.7^{\circ} \mathrm{W}$, elevation $1208 \mathrm{~m}$ ). The maximum daytime temperature was $\approx 35^{\circ} \mathrm{C}$, and minimum nighttime temperature was $\approx 23^{\circ} \mathrm{C}$. Metal halide lamps were used to supplement sunlight to maintain a 14-h photoperiod. Lamps were kept $1.5 \mathrm{~m}$ above plants. Pots were watered at planting and checked three times weekly and watered as needed to maintain a full water profile throughout the experiments.

Plant material. Dry bean cultivars, i.e., common bean and dry edible bean, listed in Table 1, were obtained from various seed programs such as the University of Idaho, University of Saskatchewan, and Michigan State University and purchased through Kelley Bean Co., Scottsbluff, NE. Type II, indeterminate and upright, and Type III, indeterminate and prostate, cultivars are commonly grown in western Nebraska. The cv. Matterhorn and cv. Poncho were chosen as to initially represent Type II and Type III cultivars, respectively, because they are major cultivars grown in this area. Type I, determinate, cultivars are not commonly grown in this area, but as a result of the range of responses to $\mathrm{GA}_{3}$ application of Type II and III cultivars, Type I cultivars 
Table 1. Dry bean cultivars, their market class and type, used in greenhouse studies, and a summary of the $\mathrm{GA}_{3}$ concentration applied to the unifoliate leaves that resulted in the maximum stimulation of internode elongation (combination of 3 years' data).

\begin{tabular}{|c|c|c|c|c|}
\hline Cultivar & Market class & Type & $\begin{array}{c}\mathrm{GA}_{3} \text { concn } \\
\text { for maximum } \\
\text { response }(\mathrm{ppm})\end{array}$ & $\begin{array}{c}\text { Relative } \mathrm{GA}_{3} \\
\text { foliar sensitivity } \\
\text { level }^{\mathrm{z}}\end{array}$ \\
\hline$\overline{\text { Poncho }^{y}}$ & Pinto & III $^{x}$ & 2 & High \\
\hline Marquis & Great Northern & III & 8 & High \\
\hline Frigate & Navy & II & 0.5 & High \\
\hline Vision & Pinto & II & 32 & Medium \\
\hline Matterhorn $^{\mathrm{y}}$ & Great Northern & II & 512 & Medium \\
\hline Ensign & Navy & II & 512 & Medium \\
\hline Agate & Pinto & I & 0.125 & High \\
\hline Amber & Pinto & I & 8 & High \\
\hline CDC Pintium & Pinto & I & 8 & High \\
\hline Doray & Pinto & I & 0.125 & High \\
\hline Early Ray & Pinto & I & 8 & High \\
\hline G2883 & Great Northern & I & 0.125 & High \\
\hline Nordic & Great Northern & I & 512 & Medium \\
\hline Newport & Navy & I & 512 & Medium \\
\hline Seafarer & Navy & I & 512 & Medium \\
\hline Foxfire & Light Red Kidney & $\mathrm{I}$ & 512 & Medium \\
\hline Pink Panther & Light Red Kidney & I & 512 & Medium \\
\hline Rog 776 & Light Red Kidney & $\mathrm{I}$ & 512 & Medium \\
\hline Moldova-104 & Large White Kidney & $\mathrm{I}$ & 2048 & Low \\
\hline
\end{tabular}

${ }^{z}$ Relative sensitivity was based on the concentration of foliar-applied $\mathrm{GA}_{3}$ that resulted in the maximum stimulation of internode elongation: high $=8 \mathrm{ppm}$ or less, medium $=32-512 \mathrm{ppm}$, low $=2048 \mathrm{ppm}$ or greater.

y'Matterhorn' and 'Poncho' were the standards for Type II and Type III cultivars and for medium and high $\mathrm{GA}_{3}$ sensitivity, respectively.

${ }^{\mathrm{x}}$ Type III cultivars are prostate (viny) and indeterminate. Type II cultivars are bushy (erect) and indeterminate. Type I cultivars are determinate and bushy.

$\mathrm{GA}_{3}=$ gibberellic acid .

were also tested for their foliar response. Seeds were treated with streptomycin for pathogen suppression by Kelley Bean Co. using standard commercial practices.

In the 2005 rate tests, seeds were planted in durable molded fiber pots that were $20 \mathrm{~cm}$ in diameter and $20 \mathrm{~cm}$ deep. In the tests conducted in 2006 and 2007, seeds were planted in plastic pots, $15 \mathrm{~cm}$ in diameter by $15 \mathrm{~cm}$ deep, because of acceptability, availability, and bench space limitation. Seeds were planted $2 \mathrm{~cm}$ deep in Fafard Superfine Germination Mix (American Clay Works, Denver, CO). In the seed application tests in 2005 , emergence of all planted seeds and plant height of all emerged seedlings were determined. In all tests in which $\mathrm{GA}_{3}$ was applied to the foliage, four seeds were planted per pot and thinned after a few days to three plants before treatment for uniformity. On a per-cultivar basis, four pots were used for each $\mathrm{GA}_{3}$ treatment. Pots were arranged in an randomized complete block design based on $\mathrm{GA}_{3}$ treatment separated by cultivar on a greenhouse bench. The heights of nodes and apices were measured, and emergence and flowering were observed. Experiments were analyzed using SAS Proc analysis of variance and means were separated using least significant difference (SAS Institute, 2003) for each cultivar separately.

Chemical preparation. Gibberellic acid was applied as Release LC, a 4\% a.i. weight by weight, i.e., $1 \mathrm{~g} \mathrm{GA}_{3} / 30 \mathrm{~mL}$, formulation (Valent BioScience Corp., Long Grove, IL). Release LC was diluted serially with water from 16,000 to $0.031 \mathrm{ppm} \mathrm{GA}_{3}$. A stickerspreader-type surfactant, $X 77$, at $0.125 \%$ was added to solutions applied to foliage until determined not to be needed in a greenhouse test in 2007 (unpublished data).

Seed application experiments. Emergence tests were conducted in 2005 when 32 seeds of 'Matterhorn' and 'Poncho' were soaked in $15 \mathrm{~mL} \mathrm{GA}_{3}$ solutions for $5 \mathrm{~min}$. Seeds were removed and air-dried for 2 to $3 \mathrm{~h}$ at $20{ }^{\circ} \mathrm{C}$ and then planted in pots placed in the greenhouse in 2005. Three seeds of each seed treatment of the two cultivars were planted together into each of four pots and were used as replicates. Therefore, the treatments were paired per pot while the pots were placed randomly by replication on a greenhouse bench. Emergence was determined at $7 \mathrm{~d}$ after planting (DAP) and height of unifoliate and trifoliate nodes were measured at 9 and 14 DAP.

Foliar application method. Foliar applications were made to the unifoliate leaves at Stage V2 (Schwartz et al., 1993), which was reached between 10 and 14 DAP. Cosmetic squirt bottles $(59 \mathrm{~mL})$ were used to apply $\approx 1$ $\mathrm{mL}$ (seven squirts) to the two unifoliate leaves $(0.5 \mathrm{~mL} / \mathrm{leaf})$. The rates of $\mathrm{GA}_{3}$ in the initial dose test in 2005 ranged from 0.03125 to $2048 \mathrm{ppm}$ increased by increments of $2 \times$, i.e., $0.03125,0.0625,0.125$, 0.25 , etc.

Cultivar sensitivity tests. In 2006, the doses were individualized to the cultivar types as a result of differential sensitivity between 'Matterhorn' (Type II) and 'Poncho' (Type III) observed in 2005 in the foliar application experiments. Nine cultivars were tested to determine whether they would show a wide range of $\mathrm{GA}_{3}$ sensitivity and could be grouped based on their sensitivity to $\mathrm{GA}_{3}$ in 2006. Cultivars CDC Pintium, Nordic, and
Seafarer were classified as Type I; cultivars Ensign, Frigate, Matterhorn, and Vision were as Type II; and cultivars Marquis and Poncho were classified as Type III. The market class represented were Pinto (cvs. CDC Pintium, Poncho, and Vision), Great Northern (cvs. Marquis, Matterhorn, and Nordic), and Navy (cvs. Ensign, Frigate, and Seafarer) (Table 1). Cultivars Poncho, Marquis, and Frigate were treated with $\mathrm{GA}_{3}$ at $0,0.125,0.5,2,8$, and 32 ppm applied to the unifoliate leaves 10 DAP (V2); and cultivars Matterhorn, Vision, Ensign, CDC Pintium, Nordic, and Seafarer were treated with $\mathrm{GA}_{3}$ at $0,8,32,128,512$, and $2048 \mathrm{ppm}$. Height to the unifoliate node, i.e., plant height at time of treatment, was measured at treatment and measured again along with heights to the first and second trifoliate nodes and the plant apex at 7 DAT. New growth at 7 DAT was defined as the height of the plant apex at 7 DAT minus the plant height at the time of $\mathrm{GA}_{3}$ application (10 DAP), i.e., the height of the unifoliate node. As a result of the responsiveness of the Type I cultivars in 2006, 13 Type I cultivars were tested in 2007. These cultivars represented five market classes, 'Pinto', 'Great Northern', 'Navy', 'Light Red Kidney', and 'Large White Kidney' (Table 1). Unifoliate leaves were treated at $12 \mathrm{DAP}$ with $\mathrm{GA}_{3}$ at $0,0.125,8$, 512 , and $2048 \mathrm{ppm}$. These rates were chosen based on the 2006 results. Apical height was measured at 7 DAT.

\section{Results}

Seed application (2005). Emergence from pots in the greenhouse of 'Matterhorn' seed treated with $16,000 \mathrm{ppm} \mathrm{GA}_{3}$ was $25 \%$, significantly less than for both water-treated checks $(75 \%)$ and seed treated with 63 to $4000 \mathrm{ppm} \mathrm{GA}_{3}(67 \%$ to $83 \%)$. In contrast, 'Poncho' did not show a significant effect of $\mathrm{GA}_{3}$ seed treatment on emergence at any treatment level $(67 \%$ to $75 \%)$. At 14 DAP, the height of the unifoliate and first trifoliate nodes was measured. Stem elongation promotion by $\mathrm{GA}_{3}$ was highly significant (Fig. 1). 'Poncho' grew more than 'Matterhorn' and its nodes were higher. Significant height promotion was obtained between 250 and 1000 ppm $\mathrm{GA}_{3}$. Maximum stimulation by $\mathrm{GA}_{3}$ was reached at $1000 \mathrm{ppm}$ for 'Poncho' and 2000 ppm for 'Matterhorn', indicating a possible difference in sensitivity.

Foliar application (2005). The rate response of 'Matterhorn' and 'Poncho' to $\mathrm{GA}_{3}$ applied to unifoliate leaves at V2 was tested also in 2005. Initially, $\mathrm{GA}_{3}$ was applied at 2 to $2048 \mathrm{ppm}$ in $2 \times$ increments (Fig. 2). 'Matterhorn' showed significant height promotion of the first trifoliate node after 1 week exposure to $64 \mathrm{ppm} \mathrm{GA}_{3}$ or greater and the response reached a plateau at $256 \mathrm{ppm} \mathrm{GA}_{3}$. 'Poncho' was much more sensitive to $\mathrm{GA}_{3}$ than 'Matterhorn' (Fig. 2). Within 7 DAT, it was clear that 'Poncho' was affected by $2 \mathrm{ppm}$. The rate response was repeated with lower doses, 0.031 to $4 \mathrm{ppm} \mathrm{GA}_{3}$. Significant height promotion of the first and second trifoliate nodes at 7 DAT was observed with $0.25 \mathrm{ppm}$ 


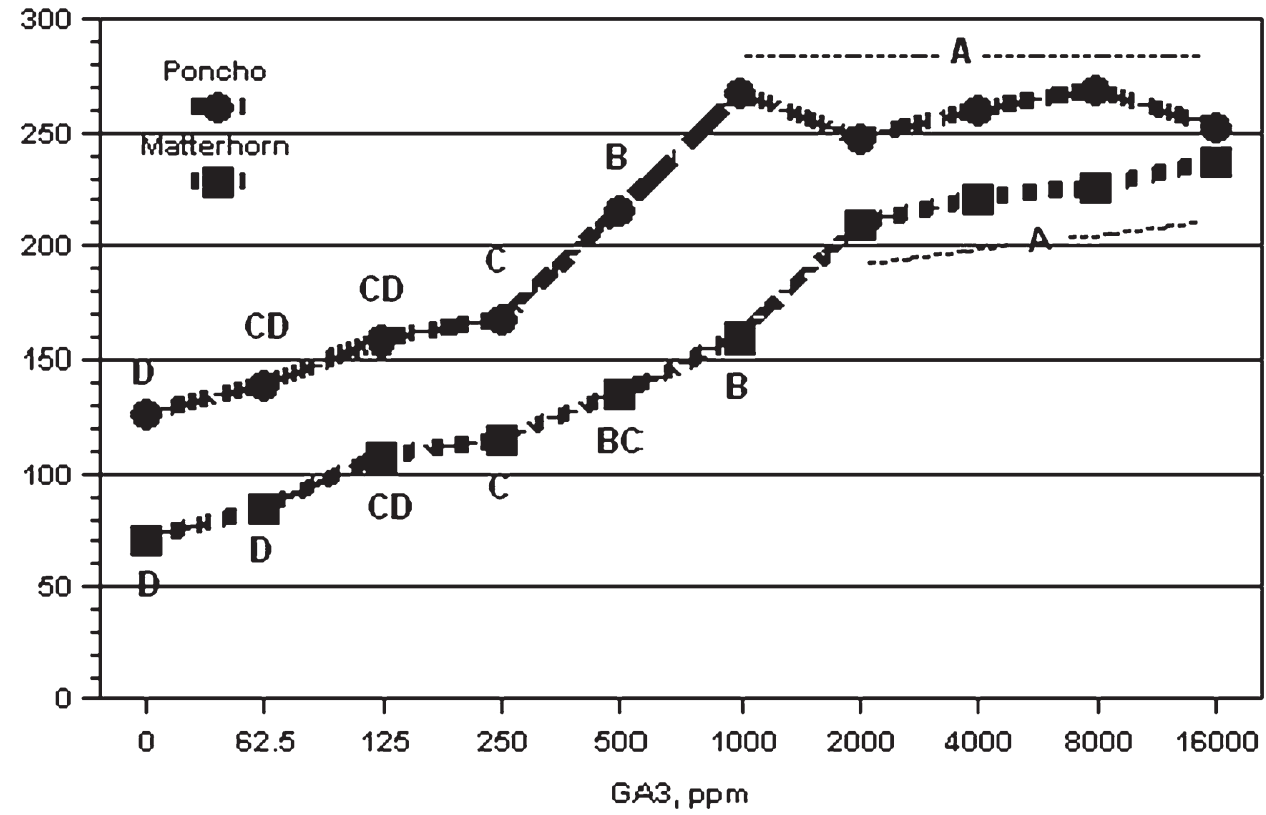

height, $\mathrm{mm}$

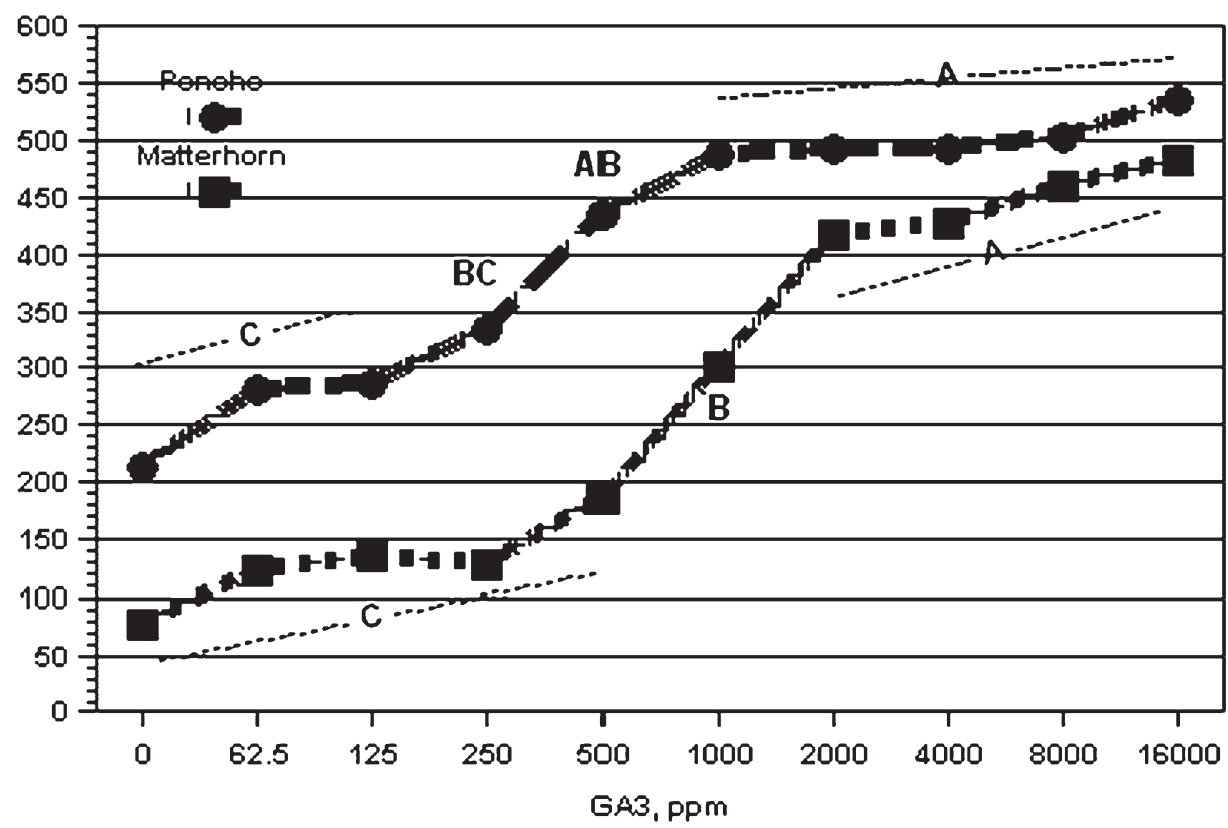

Fig. 1. Height of the unifoliate (A) and first trifoliate (B) nodes of dry bean cultivars Poncho and Matterhorn 2 weeks after planting seed treated with gibberellic acid $\left(\mathrm{GA}_{3} ; 2005\right)$. Means separated between $\mathrm{GA}_{3}$ doses for each cultivar (curve) by least significant difference at $P<0.05$.

$\mathrm{GA}_{3}$ applied to unifoliate leaves and the response reached a plateau at $4 \mathrm{ppm} \mathrm{GA}_{3}$ (Fig. 2). When 'Poncho' plants were held to 21 and 35 DAT to observe floral and subsequent pod development, $\mathrm{GA}_{3}$ at $32 \mathrm{ppm}$ and greater had a significant inhibiting effect on flowering and pod formation (Fig. 3). No flowers or pods were present on 'Poncho' plants exposed to $128 \mathrm{ppm} \mathrm{GA}_{3}$ and greater. A similar effect was not observed with 'Matterhorn' (data not shown); floral and pod development showed no significant difference between water-treated checks and plants treated with up to 2048 ppm $\mathrm{GA}_{3}$.
Cultivar sensitivity (2006, 2007). Because results in 2005 showed that $\mathrm{GA}_{3}$ applied to the unifoliate leaves at V2 affected the internode length above the unifoliate node (Fig. 2), new growth, i.e., difference between the plant height at treatment and that at 7 DAT, should be indicative of a $\mathrm{GA}_{3}$ effect. In 2006, nine cultivars were used, some of Type I, Type II, or Type III with three cultivars being in one of three market classes, 'Great White Northern', 'Pinto', or 'Navy' market class (Table 1). Cultivars Marquis and Poncho, both Type III, and Type II cultivar Frigate reached a plateau in the amount of new growth when exposed to $\mathrm{GA}_{3}$ at less than 8 ppm (Table 2). 'Frigate' is a Type IIB cultivar that can be viny, behaving similar to a Type IIIA cultivar in the environment of western Nebraska. The Type II cultivar Vision attained a plateau in new growth with $\mathrm{GA}_{3}$ at $32 \mathrm{ppm}$, whereas the other two Type II cultivars, Ensign and Matterhorn, attained a plateau in new growth response with $\mathrm{GA}_{3}$ at $512 \mathrm{ppm}$ (Table 2). Cultivar Poncho's higher sensitivity and cv. Matterhorn's lower sensitivity to $\mathrm{GA}_{3}$ was at the same level as observed in 2005 (Fig. 2). The three Type I cultivars, CDC Pintium, Nordic, and Seafarer 


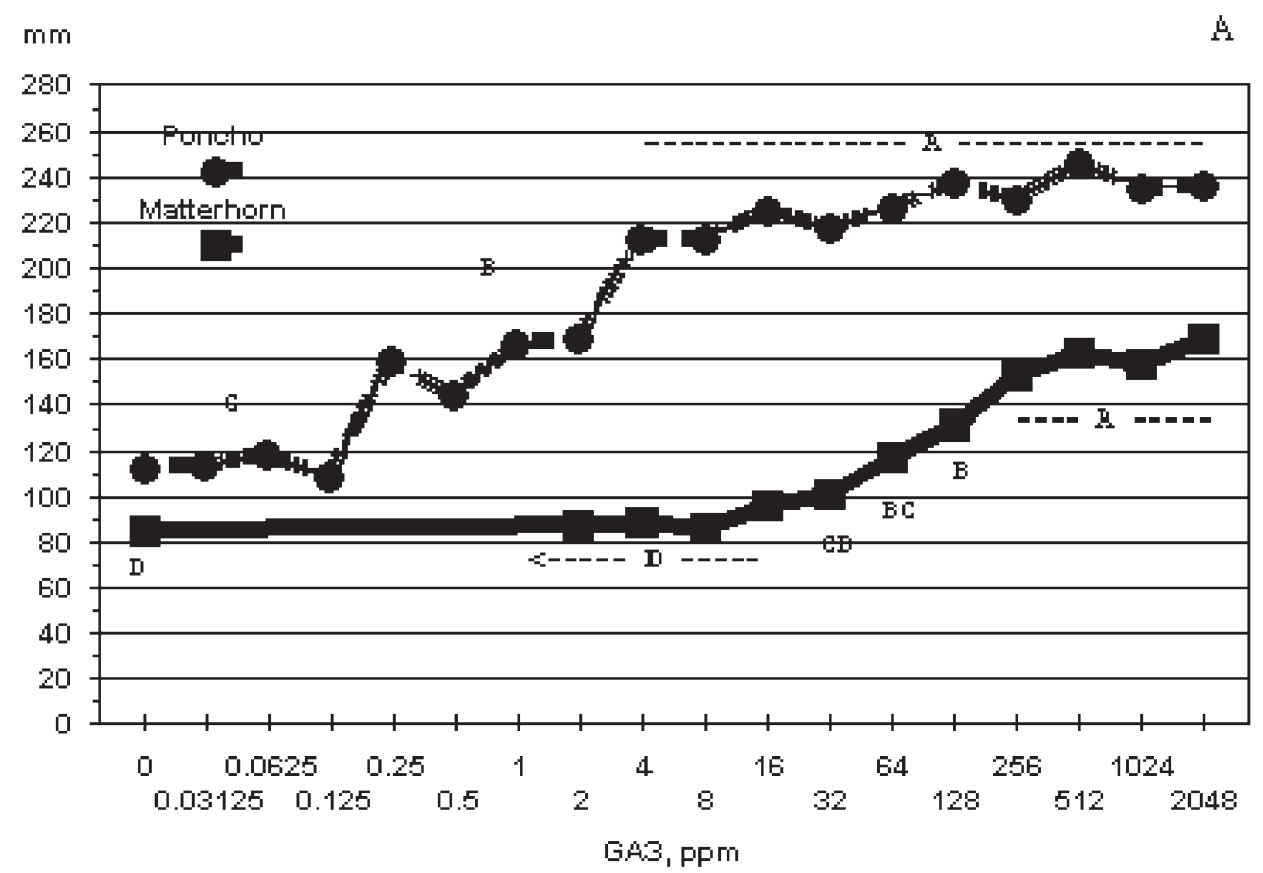

$\mathrm{B}$

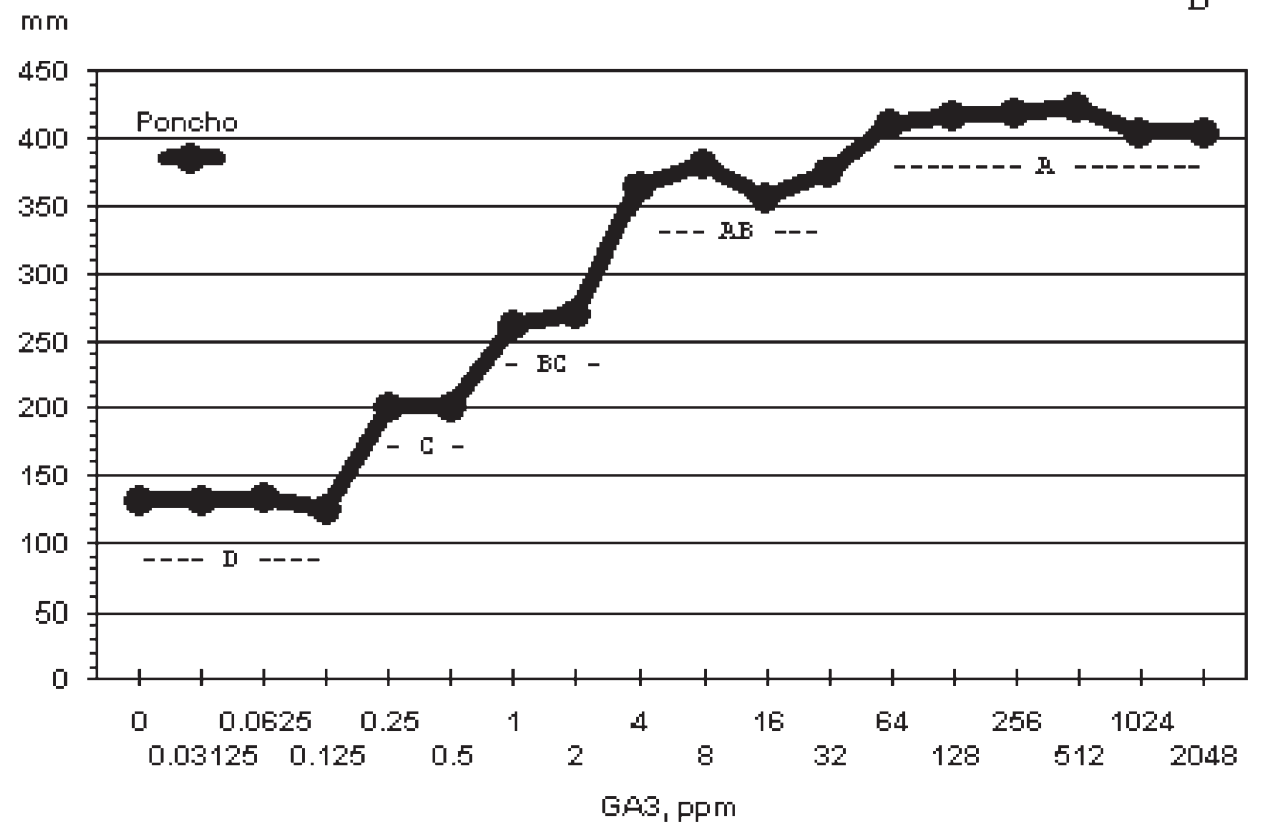

Fig. 2. Height of the first trifoliate nose of dry bean cultivars Poncho and Matterhorn (A) and the second trifoliate node of the cultivar Poncho (B) 1 week after treating unifoliate leaves with gibberellic acid $\left(\mathrm{GA}_{3} ; 2005\right)$. 'Matterhorn' had not developed the second trifoliate node at this time. Means separated between $\mathrm{GA}_{3}$ doses for each cultivar (curve) by least significant difference at $P<0.05$.

showed a sensitivity plateau between 8 and $32 \mathrm{ppm}$ (Table 2). Although a statistical comparison was not possible, market class, which is based on seed characteristics, did not show a pattern to $\mathrm{GA}_{3}$ sensitivity. In 2007, 13 Type I cultivars (Table 1) were tested. Type I cultivars reacted to $\mathrm{GA}_{3}$ doses in three groupings classified by the degree of cultivar sensitivity to $\mathrm{GA}_{3}$ (Table 3). Cultivars Agate, Amber, CDC Pintium, Doray, Early Ray, and G2883 reached a sensitivity plateau at or below 8 ppm $\mathrm{GA}_{3}$ similar to Type III cultivars and the Type II cultivar Frigate. Cultivars Nordic, Newport, Seafarer, Foxfire, Pink Panther, and Rog 776 reached a plateau between 8 and 512 ppm $\mathrm{GA}_{3}$ similar to 'Matterhorn', 'Vision', and 'Ensign' (Table 3). The cultivar Moldova 104 did not reach a maximum elongation stimulation until exposed to $2048 \mathrm{ppm}$ $\mathrm{GA}_{3}$ or greater indicating a lower level of sensitivity than the other cultivars (Table 3 ).

\section{Discussion}

Gibberellic acid dose-response. A cultivarspecific stem elongation response to $\mathrm{GA}_{3}$ was first observed with seed treatments. 'Poncho', a Type III cultivar, showed elongation of the stem below the first trifoliate internode with one-fourth to half the concentration needed by 'Matterhorn', a Type II cultivar, to reach maximum effect. Foliar $\mathrm{GA}_{3}$ application resulted in a similar effect but with lower $\mathrm{GA}_{3}$ doses and showing a greater difference in dose-response between the two cultivars. Much lower $\mathrm{GA}_{3}$ rates applied to foliage significantly stimulated stem elongation for 'Poncho' compared with 'Matterhorn' (Fig. 2). On snap bean (P. vulgaris), the $\mathrm{GA}_{3}$ exposures of unifoliate leaves at V2 that resulted in maximum elongation of the internode above the unifoliate within 1 week after exposure were between 2 and $10 \mu \mathrm{g} /$ leaf or $1 \mathrm{~mL}$ of a 10 ppm solution (Bukovac et al., 1958; Knoche and Bukovac, 1999; Knoche et al., 1998, 2000; 
reproductive stage

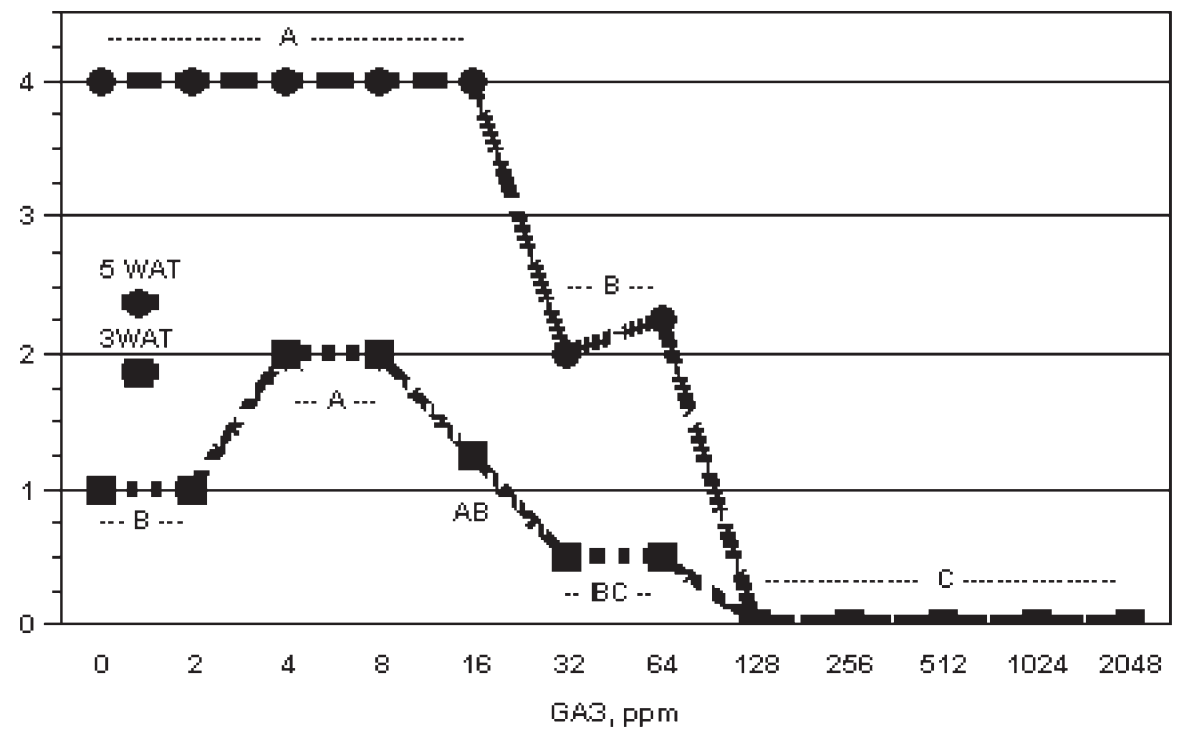

Fig. 3. Floral stage of dry bean cultivar Poncho 3 and 5 weeks after treating (WAT) unifoliate leaves with gibberellic acid $\left(\mathrm{GA}_{3} ; 2005\right)$. Reproductive scale indicates presence of no flowers $(0)$, closed flowers (1), open flowers (2), small pods, less than $2.5 \mathrm{~cm}$ (3), and large pods, greater than 2.5 (4). Means separated between $\mathrm{GA}_{3}$ doses for each WAT (curve) by least significant difference at $P<0.05$.

Table 2. New growth of Type I, II and III cultivars 1 week after exposure of unifoliate leaves to gibberellic acid (2006)

\begin{tabular}{|c|c|c|c|c|c|c|c|}
\hline \multirow[b]{3}{*}{ Cultivar } & \multirow[b]{3}{*}{ Type } & \multicolumn{6}{|c|}{$\mathrm{GA}_{3}$ exposure (ppm) } \\
\hline & & 0 & 0.125 & 0.5 & 2 & 8 & 32 \\
\hline & & \multicolumn{6}{|c|}{ New growth $(\mathrm{mm})^{\mathrm{z}}$} \\
\hline$\overline{\text { Poncho }^{y, x}}$ & III $^{\mathrm{w}}$ & $504 \mathrm{D}^{\mathrm{v}}$ & $557 \mathrm{CD}$ & $642 \mathrm{BC}$ & $719 \mathrm{AB}$ & $695 \mathrm{AB}$ & $762 \mathrm{~A}$ \\
\hline Marquis & III & $109 \mathrm{C}$ & $212 \mathrm{~B}$ & $222 \mathrm{~B}$ & 294 B & $447 \mathrm{~A}$ & $464 \mathrm{~A}$ \\
\hline \multirow[t]{3}{*}{ Frigate } & II & $380 \mathrm{BC}$ & $326 \mathrm{C}$ & $496 \mathrm{AB}$ & $518 \mathrm{~A}$ & $625 \mathrm{~A}$ & $531 \mathrm{~A}$ \\
\hline & & \multicolumn{6}{|c|}{$\mathrm{GA}_{3}$ exposure (ppm) } \\
\hline & & 0 & 8 & 32 & 128 & 512 & 2048 \\
\hline Cultivar & Type & \multicolumn{6}{|c|}{ New growth $(\mathrm{mm})$} \\
\hline Vision & II & $121 \mathrm{C}$ & $234 \mathrm{~B}$ & $514 \mathrm{~A}$ & $573 \mathrm{~A}$ & $600 \mathrm{~A}$ & $563 \mathrm{~A}$ \\
\hline Matterhorn & II & $147 \mathrm{C}$ & $162 \mathrm{C}$ & $407 \mathrm{~B}$ & $473 \mathrm{~B}$ & $590 \mathrm{~A}$ & $604 \mathrm{~A}$ \\
\hline Ensign & II & $66 \mathrm{D}$ & $109 \mathrm{D}$ & $269 \mathrm{C}$ & $381 \mathrm{~B}$ & $484 \mathrm{~A}$ & $468 \mathrm{~A}$ \\
\hline CDC Pintium & I & $465 \mathrm{~B}$ & $530 \mathrm{~B}$ & $582 \mathrm{AB}$ & $571 \mathrm{AB}$ & $570 \mathrm{AB}$ & $671 \mathrm{~A}$ \\
\hline Nordic & I & $326 \mathrm{~B}$ & $554 \mathrm{AB}$ & $622 \mathrm{~A}$ & $615 \mathrm{~A}$ & $647 \mathrm{~A}$ & $637 \mathrm{~A}$ \\
\hline Seafarer & $\mathrm{I}$ & $226 \mathrm{C}$ & $427 \mathrm{~B}$ & $486 \mathrm{AB}$ & $508 \mathrm{AB}$ & $577 \mathrm{~A}$ & $563 \mathrm{~A}$ \\
\hline
\end{tabular}

${ }^{\mathrm{z} N e w}$ growth was calculated as the plant height $7 \mathrm{~d}$ after treatment minus the plant height at time of treatment.

'Poncho', 'Vision', and 'CDC Pintium' are in the market class Pinto; 'Marquis', 'Matterhorn', and 'Nordic' are in the market class Great White Northern; and 'Frigate', 'Ensign', and 'Seafarer' are in the market class Navy.

'Matterhorn' and 'Poncho' were the standards for Type II and Type III cultivars and for low and high GA sensitivity, respectively.

wType III cultivars are prostate (viny) and indeterminate. Type II cultivars are bushy (erect) and indeterminate. Type I cultivars are generally reported bushy (erect) and determinate.

${ }^{\vee}$ Mean separation for each cultivar (rows) by least significant difference at $P<0.05$.

$\mathrm{GA}_{3}=$ gibberellic acid.

Marth et al., 1956). None of the snap bean cultivars were characterized as upright or erect but as prostate or pole type. This range of sensitivity was the same as observed with the cvs. Poncho and Marquis, Type III cultivars (indeterminate prostate), one Type IIB cultivar, Frigate, and six Type I (determinate) cultivars that showed maximum stimulation to less than $8 \mu \mathrm{g} \mathrm{GA}_{3} /$ plant (or 8 ppm) (Tables 2 and 3). 'Vision', a Type IIB, semiupright, reached a maximum response with $32 \mathrm{ppm} \mathrm{GA}_{3}$. The other
Cultivar sensitivity. The genetics of gibberellin sensitivity in common bean cultivars seemed to be highly variable and may be grouped into at least two categories based on their sensitivity to $\mathrm{GA}_{3}$. Type I cultivars showed a mixed response to $\mathrm{GA}_{3}$, from low to high doses. Unlike indeterminate cultivars, Type I cultivars (determinate) are loosely described as bushy. Based on their $\mathrm{GA}_{3}$ response, some Type I cultivars may be less sensitive to $\mathrm{GA}_{3}$, similar to the Type II cultivar Matterhorn; other Type I cultivars may be more sensitive to $\mathrm{GA}_{3}$, similar to the Type III cultivar Poncho. In the present study, significant differences in response to $\mathrm{GA}_{3}$ doses were observed among cultivars regardless of their growth habit, e.g., erect/upright vs. prostate/viny, determinate vs. indeterminate. Dry bean cultivars with a similar sensitivity to $\mathrm{GA}_{3}$ dose may have similar genetics related to gibberellin response.

\section{Conclusion}

This study showed that stem elongation of common bean cultivars responds to different doses of $\mathrm{GA}_{3}$ and that this difference may be categorized in at least two groups, high and medium $\mathrm{GA}_{3}$ sensitivity. $\mathrm{GA}_{3}$ sensitivity could not be correlated to determinate vs indeterminate, growth habit, e.g., erect/upright/ bush vs. prostate/viny, or to market class. Individual cultivars would need to be evaluated in a short-term foliar bioassay for their specific $\mathrm{GA}_{3}$ sensitivity before applying $\mathrm{GA}_{3}$ in the field to raise lower pods and improve direct harvest.

\section{Literature Cited}

Bukovac, M.J., S.H. Wittwer, and B.K. Gaur. 1958. Some factors influencing the response of the bean (Phaseolus vulgaris L.) to gibberellin. Mich. Qrtly. Bul. 41:296-302.

Davies, P.J. (ed.). 2010. Plant hormones: Biosynthesis, signal transduction, action. 3rd Ed. SpringerVerlag, New York, NY.

Eckert, F.R., H.J. Kandel, B.L. Johnson, G.A. RojasCifuentes, C. Deplazes, A.J. Vander Wal, and J.M. Osorno. 2011. Seed yield and loss of dry bean cultivars under conventional and direct harvest. Agron. J. 103:129-136.

Gepts, P. 1998. Origin and evolution of common bean: Past events and recent trends. HortScience 33:1124-1129.

Kelly, J.D. 2001. Remaking bean plant architecture for efficient production. Adv. Agron. 71:109143.

Knoche, M. and M.J. Bukovac. 1999. Spray application factors and plant growth regulator performance: II. Foliar uptake of gibberellic acid and 2,4-D. Pestic. Sci. 55:166-174.

Type II cultivars, Matterhorn and Ensign (indeterminate upright or erect stature), and seven Type I cultivars may require as much as $512 \mathrm{ppm}\left(512 \mu \mathrm{g} \mathrm{GA}_{3} /\right.$ plant $)$ to show maximum stimulation of internode elongation above the node of application (Tables 2 and 3 ). There was as much as a 64-fold difference between the $\mathrm{GA}_{3}$ sensitivity of 'Matterhorn' vs. 'Poncho' (Fig. 2). One Type I cultivar required $2048 \mathrm{ppm} \mathrm{GA}_{3}$ for maximum promotion of stem elongation (Table 3).
Knoche, M., M.J. Bukovac, S. Nakagawa, and G.D Crabtree. 1998. Spray application factors and plant growth regulator performance: I. Bioassays and biological response. Pestic. Sci. 54:168178 .

Knoche, M., N.K. Lownds, and M.J. Bukovac. 2000. Spray application factors and plant growth regulator performance: IV. Dose response relationships. J. Amer. Soc. Hort. Sci. 125:195-199.

Koinange, E.M.K., S.P. Singh, and P. Gepts. 1996. Genetic control of the domestication syndrome in common bean. Crop Sci. 36:1037-1045. 
Kretchmer, P.J. and D.H. Wallace. 1978. Inheritance of growth habit in indeterminate lines of Phaseolus vulgaris L. Annu. Rep. Bean Improv. Coop. 21:29-30.

Laing, D.R., P.G. Jones, and J.H.C. Davis. 1984. Common bean, p. 305-351. In: Goldsworthy, P.R. and N.M. Fisher (eds.). The physiology of tropical field crops. Wiley, New York, NY.

Marth, P.C., W.V. Audia, and J.W. Mitchell. 1956. Effects of gibberellic acid on growth and development of plants of various genera and species. Bot. Gaz. 118:106-111.
Miklas, P.N. and S.P. Singh. 2007. Common bean, p. 1-31. In: Kole, C. (ed.). Genome mapping and molecular breeding in plants, Vol. 3. Pulses, sugar and tuber crops. Springer-Verlag, New York, NY.

SAS Institute. 2003. SAS system for Windows. Release 9.1. SAS Institute Inc., Cary, NC.

Schwartz, H.F., M.S. McMillan, and M.A. Brick. 1993. Colorado dry bean production and IPM. Col. State Univ. Bul. 548A.

Singh, S.P. 1982. A key for identification of different growth habits of Phaseolus vulgaris
L. Annu. Rep. Bean Improv. Coop. 25:9295.

Singh, S.P. 2001. Breeding the genetic base of common bean cultivars: A review. Crop Sci. 41:1659-1675.

Smith, J.A. 2004. Harvest, p. 59-69. In: Schwartz, H.F., M.A. Brick, R.M. Harveson, and G.D. Franc (eds.). Dry bean production \& integrated pest management. 2nd Ed. Col. State Univ. Reg Bul. 562A.

Takahashi, N., B.O. Phinney, and J. MacMillan (eds.). 1991. Gibberellins. Springer-Verlag, New York, NY.

Table 3. New growth of Type I cultivars 1 week after exposure of unifoliate leaves to gibberellic acid (2007).

\begin{tabular}{|c|c|c|c|c|c|c|}
\hline \multirow[b]{3}{*}{ Cultivar } & \multirow[b]{3}{*}{ Market class } & \multicolumn{5}{|c|}{$\mathrm{GA}_{3}$ exposure (ppm) } \\
\hline & & 0 & 0.125 & 8 & 512 & 2048 \\
\hline & & \multicolumn{5}{|c|}{ New growth $(\mathrm{mm})^{\mathrm{z}}$} \\
\hline$\overline{\text { Agate }}$ & Pinto & $488 \mathrm{~B}^{\mathrm{y}}$ & $593 \mathrm{AB}$ & $725 \mathrm{~A}$ & $743 \mathrm{~A}$ & $691 \mathrm{~A}$ \\
\hline Amber & Pinto & $487 \mathrm{BC}$ & $444 \mathrm{C}$ & $702 \mathrm{~A}$ & $648 \mathrm{AB}$ & $800 \mathrm{~A}$ \\
\hline CDC Pintium & Pinto & $309 \mathrm{C}$ & $505 \mathrm{~B}$ & $642 \mathrm{AB}$ & $725 \mathrm{~A}$ & $639 \mathrm{AB}$ \\
\hline Doray & Pinto & $520 \mathrm{~B}$ & $669 \mathrm{~A}$ & $749 \mathrm{~A}$ & $748 \mathrm{~A}$ & $616 \mathrm{AB}$ \\
\hline Early Ray & Pinto & 396 B & $429 \mathrm{~B}$ & $515 \mathrm{AB}$ & $486 \mathrm{AB}$ & $525 \mathrm{~A}$ \\
\hline G2883 & Great Northern & $424 \mathrm{~B}$ & $567 \mathrm{AB}$ & $612 \mathrm{AB}$ & $684 \mathrm{~A}$ & $697 \mathrm{~A}$ \\
\hline Nordic & Great Northern & $210 \mathrm{C}$ & $177 \mathrm{C}$ & $462 \mathrm{~B}$ & $607 \mathrm{~A}$ & $622 \mathrm{~A}$ \\
\hline Newport & Navy & $33 \mathrm{C}$ & $31 \mathrm{C}$ & $100 \mathrm{~B}$ & $418 \mathrm{~A}$ & $423 \mathrm{~A}$ \\
\hline Seafarer & Navy & $89 \mathrm{C}$ & $115 \mathrm{C}$ & $321 \mathrm{~B}$ & $523 \mathrm{~A}$ & $598 \mathrm{~A}$ \\
\hline Foxfire & Light Red Kidney & $131 \mathrm{C}$ & $143 \mathrm{C}$ & $431 \mathrm{~B}$ & $658 \mathrm{~A}$ & $700 \mathrm{~A}$ \\
\hline Pink Panther & Light Red Kidney & $279 \mathrm{C}$ & $288 \mathrm{C}$ & $522 \mathrm{~B}$ & $675 \mathrm{~A}$ & $686 \mathrm{~A}$ \\
\hline $\operatorname{Rog} 776$ & Light Red Kidney & $155 \mathrm{C}$ & $211 \mathrm{C}$ & $516 \mathrm{~B}$ & $729 \mathrm{~A}$ & $660 \mathrm{~A}$ \\
\hline Moldova 104 & Large White Kidney & $217 \mathrm{D}$ & $361 \mathrm{C}$ & $618 \mathrm{~B}$ & $668 \mathrm{~B}$ & $813 \mathrm{~A}$ \\
\hline
\end{tabular}

zNew growth was calculated as the plant height $7 \mathrm{~d}$ after treatment minus the plant height at time of treatment.

${ }^{\mathrm{y}}$ Mean separation for each cultivar (rows) by least significant difference at $P<0.05$.

$\mathrm{GA}_{3}=$ gibberellic acid. 